\title{
Littoral invertebrates associated with aquatic plants and bioassessment of ecological status in Lake Bracciano (Central Italy)
}

\author{
Luciana MASTRANTUONO* and Teresa MANCINELLI \\ Dept. of Animal and Human Biology, Univ. "La Sapienza", Viale dell'Università 32, 00185 Rome, Italy \\ *e-mail corresponding author: luciana.mastrantuono@uniroma1.it
}

\begin{abstract}
Lake Bracciano is a large and deep volcanic lake which plays an unquestionable role for drawing water source and for fishing and recreational activities. The existence of a project aimed at increasing the amount of water drawn from the lake suggested the advisability of undertaking an ecological analysis of the invertebrate community associated with aquatic plants in order to obtain a detailed knowledge of its composition, biodiversity and quantitative structure, and to provide a set of basic and essential information for defining the ecological status in the littoral zone and for future bioassessments in the lake ecosystem. A good water quality, approaching oligotrophy, was evidenced both from data on aquatic vegetation, which showed the extensive colonization of Charales (down to a depth of about $20 \mathrm{~m}$ ), and from faunal parameters such as high species richness and diversity values, presence and abundance of bioindicator taxa (mainly cladocerans and gastropods), abundances of total fauna. Nevertheless, a considerable disappearance of the reed thicket due to the intense shore management for recreational purposes have negatively influenced the colonization of the more shallow and productive waters, so evidencing a negative trend of the littoral quality.
\end{abstract}

Key words: littoral zone, invertebrates, submerged plants, biodiversity, bioassessment

\section{INTRODUCTION}

The environmental control of Lake Bracciano plays a great interest because it is one of the largest and deepest Italian lakes and represents one of the most relevant water supply source for the city of Rome. Human utilization of the water dates back to ancient times (emperor Trajan's aqueduct, built in 110 A.D.) and continues today. Trajan aqueduct was restored in 1612 and later (1828) a connecting tunnel between Lake Martignano and Lake Bracciano was built to increase the aqueduct flow rate. The progressive urbanization of the surrounding areas made necessary, in the years 1982-84, to built a collector of organic wastes around the lake, connected with a sewage treatment plant (Bruno 1985; Martini 1985), which discharges the treated waters into the only lake effluent (Arrone River).

Despite the absence of important organic wastes along the shores, local phenomena of water quality deterioration depend on some small inlets discharging into the lake and not connected to the sewage system, on some cultivated areas and on the intense recreational use of the sandy beaches.

Given the unquestionable role of Lake Bracciano for drawing water supplies, fishing and recreational activities, it is rather surprising that so few papers have been published on its lacustrine fauna. The first analyses referred only to zooplankton composition (Losito 1904; Sommani 1961) and later a multidisciplinary research regarding both chemical and biological characteristics (Barbanti et al. 1971) indicated a good water quality, confirmed by further studies carried out on physico- chemical parameters (Gaggino et al. 1985), zooplankton (Ferrara 1984; Ferrara et al. 2002), littoral and profundal zoobenthos (Bazzanti 1981; Mastrantuono 1995; Bazzanti \& Seminara 2003).

In recent years the company that manages Trajan aqueduct planned to increase water captation by the pipeline and it suggested the advisability of undertaking an ecological analysis of the invertebrates associated with aquatic plants before a water level reduction, which can seriously damage this substrate. As well known aquatic plants represent a fundamental substrate in the improvement of water clarity, because vegetation prevents the erosion of the shores and the washing away of materials from the surrounding land. Moreover the plants uptake nutrients for their tissues and constitute a substrate for periphyton growth, which is a food source for grazing invertebrates, which contribute at an efficient nutrient recycling up to highest levels of the food chain (Dieter 1990; James \& Barko 1990; Jeppesen et al. 1997; Horppila \& Nurminen 2001; Blindow et al. 2002). Vegetation represents also a refuge for invertebrates, increases its biodiversity and consequently the quality state of the ecosystem. (Timm \& Moss 1984; Lodge 1986; Brönmark 1989; Blindow et al. 2000; James et al. 2000).

The great importance of these feedback mechanisms on lake metabolism makes this community very interesting for establish environmental quality, as recognized by the recent inclusion of macroinvertebrates assemblages in the Water Framework Directive (CEC 2000). Recently, the full validity of this inclusion in european biomonitoring procedures has been also extensively 


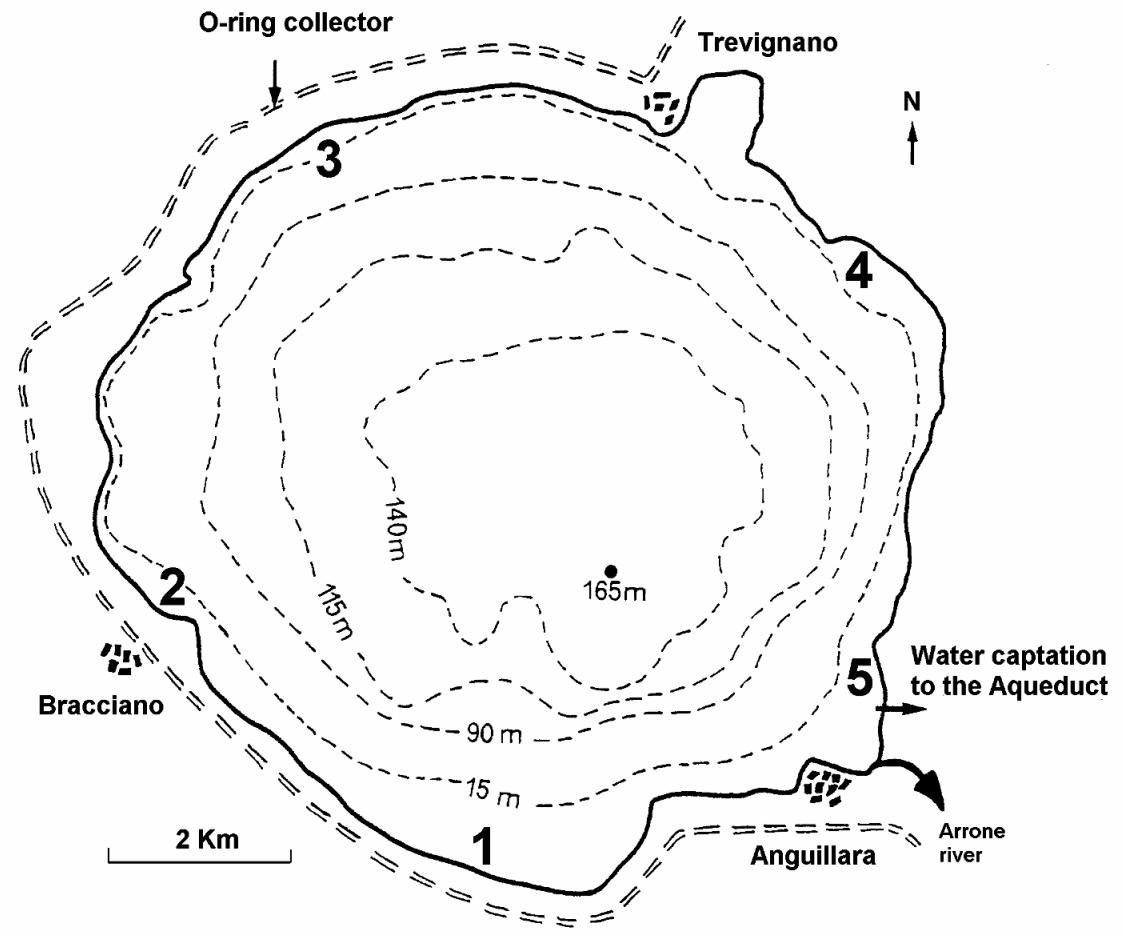

Fig. 1. Map of Lake Bracciano and location of the sampling stations.

emphasized by White \& Irvine (2003). In this picture previous studies on littoral invertebrates in lakes of Central Italy (Mastrantuono 1986, 1987, 1990, 1991, 1993; Mastrantuono \& Mancinelli 1999, 2003) have demonstrated their uselfulness because pointed on the identification of several faunal parameters which can be considered fully valid for a biomonitoring programme.

For this reason also the investigation in Lake Bracciano was aimed to obtain a detailed knowledge of the littoral invertebrate composition and biodiversity, essential both to define the lake ecological status and to have a data set available for future comparative analyses, necessary to control changes of environmental quality after possible important impacts on littoral areas.

\section{METHODS AND PHYSICO-CHEMICAL PARAMETERS}

Lake Bracciano has volcanic origin (perimeter: 31.5 $\mathrm{km}$; surface area: $51 \mathrm{~km}^{2}$, max. depth.: $165 \mathrm{~m}$ ), is located at an altitude of $164 \mathrm{~m}$ a.s.l. in the "Monti Sabatini" area in the northern part of the Lazio Region (Central Italy). It is characterized by a long water renewal time (137 years, Gaggino et al. 1985). The pipeline of the Trajan aqueduct, which draws water at a depth of about $50 \mathrm{~m}$, is located near station 5 (Fig. 1).

The sampling was carried out bimonthly from May 1998 to February 1999 in 5 stations distributed along the entire lake perimeter (Fig. 1). The samples were taken using a sledge dredge (size: $35 \times 20 \mathrm{~cm}$, mesh size: $180 \mu \mathrm{m})$ at three depth ranges $(0-4 \mathrm{~m}, 4-8 \mathrm{~m}, 8-15 \mathrm{~m})$ for each station and date. The dredge was dragged for about $50 \mathrm{~m}$ parallel to the shoreline, following a sinusoidal path at the selected depth range. The collected material was preserved in 5\% formalin. In the laboratory the plants were separated and identified as far as possible at species level. The macroinvertebrates were sorted completely from the sample by a visual method and the meiobenthic organisms were separated into suitable subsamples at low magnification under a stereomicroscope. Shannon diversity (Margalef 1957) and quantitative similarity (PSc, Renkonen 1938) were applied to annual mean densities of the identified taxa. Qualitative similarity (QS, Sørensen 1948) was applied to the list of taxa at the stations.

At the dates of sampling temperature (Fig. 2) was measured in superficial waters $(-1 \mathrm{~m})$ with a field thermometer. Water clarity (Fig. 2) was measured at each date at the center of the lake with a Secchi disk. The only available data on total phosphorus, kindly supplied by Dr. G. Tartari (IRSA, Brugherio, Tab. 1), indicate low nutrient content in the water column.

\section{RESULTS}

\subsection{Aquatic vegetation}

The analysis of the entire lake perimeter evidenced a discontinuous presence and a reduced abundance of the reed thicket, mainly due to periodical cut down carried out by local population to promote recreational activities along several sandy beaches located around the lake. The aquatic vegetation found in the collected 


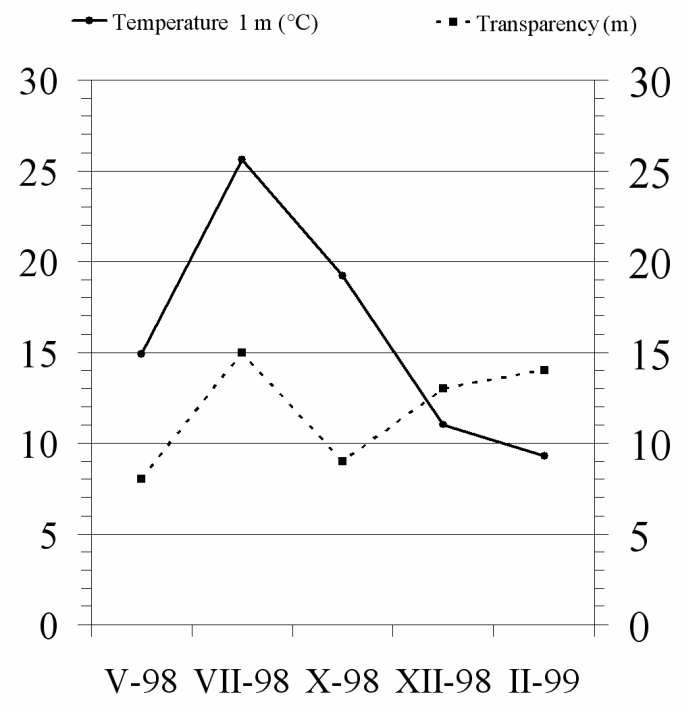

Tab. 1. Total phosphorus (TP) measured on the water column of Lake Bracciano, kindly supplied by Dr. G. Tartari (CNR, Brugherio, Milano).

\begin{tabular}{ccc}
\hline & IX-1999 & II-2000 \\
Depth $(\mathrm{m})$ & TP $\left(\mu \mathrm{g}^{-1}\right)$ & TP $\left(\mu \mathrm{g}^{-1}\right)$ \\
\hline 0.5 & - & 6 \\
1 & 6 & - \\
10 & 7 & 18 \\
20 & 12 & - \\
25 & - & 5 \\
30 & 8 & - \\
50 & 5 & - \\
75 & 6 & 3 \\
100 & 8 & - \\
140 & 10 & - \\
156 & 22 & - \\
160 & - & 8 \\
\hline
\end{tabular}

Fig. 2. Temperature and transparency (Secchi depth) in littoral area of Lake Bracciano at the sampling dates.

Tab. 2. Composition, distribution and relative abundance of the aquatic vegetation in Lake Bracciano at the stations and at the depths of sampling. $*=$ rare; $* *=$ common; $* * *=$ frequent; $* * *=$ abundant.

\begin{tabular}{|c|c|c|c|c|c|c|c|c|c|c|c|c|c|c|c|}
\hline \multirow{2}{*}{$\begin{array}{l}\text { Depths of sampling } \\
\text { Stations }\end{array}$} & \multicolumn{5}{|c|}{$0-4 \mathrm{~m}$} & \multicolumn{5}{|c|}{$4-8 \mathrm{~m}$} & \multicolumn{5}{|c|}{$8-15 \mathrm{~m}$} \\
\hline & 1 & 2 & 3 & 4 & 5 & 1 & 2 & 3 & 4 & 5 & 1 & 2 & 3 & 4 & 5 \\
\hline Characeae (sp. a) & ** & * & ** & & $*$ & * & & ** & & & $* * *$ & $* *$ & $* * * *$ & * & * \\
\hline Characeae (sp. b) & $* * * *$ & $* *$ & $* * *$ & $* * *$ & $* * *$ & $* * * *$ & $* * *$ & $* * *$ & $* * *$ & $* * * *$ & $*$ & $* *$ & $*$ & $* * * *$ & $* * *$ \\
\hline Elodea canadensis & & * & & $*$ & & & & & & & & & & & \\
\hline Myriophyllum spicatum & * & $* * *$ & & $* *$ & & & & & & & & & & & \\
\hline Ceratophyllum demersum & & $* * *$ & & * & & & $* *$ & & & & & * & & & \\
\hline Potamogeton crispus & * & & & 1 & & & & & & & & & & & \\
\hline Potamogeton perfoliatus & & * & & & & & & & & & & & & & \\
\hline Potamogeton pectinatus (?) & * & * & * & * & & & & & & & & & & * & \\
\hline Potamogeton sp. & & & & & & & & * & & & & & & & \\
\hline Nr. of taxa (total: 9) & 5 & 8 & 3 & 6 & 2 & 2 & 2 & 3 & 1 & 1 & 2 & 3 & 2 & 3 & 2 \\
\hline
\end{tabular}

samples was composed of 9 taxa, differently distributed at stations and depths (Tab. 2); the site 2 and the depth range $0-4 \mathrm{~m}$ showed the highest species richness ( 8 taxa, respectively), while the site 5 (2 taxa) and the depth range 4-8m (4 taxa) had the lowest number of taxa.

The vegetation displayed an extended colonization with depth (the maximum measure was about 18-20 m) and was mostly represented by Charales, which comprised two unidentified species, largely dominant at all stations and depths (Tab. 2). Charales were present throughout the year with moderate seasonal variations and reached considerable abundances, mostly at the depth range $8-15 \mathrm{~m}$, where covered the bottom as a thick carpet. The remaining taxa (all macrophytes) showed everywhere a patchy distribution, a presence mainly limited at the lower range (0-4 m, Tab. 2), and disappeared almost completely in the winter period.

\subsection{Fauna composition}

The benthic fauna was composed of 19 main zoological groups comprising a total of 125 taxa, identified for the most part (85\%) at species or genus level (Tab. 3 ). Chironomids were qualitatively dominant (22 taxa) and several other taxa (77) were well distributed among different and diversified groups (oligochaetes, nematodes, cladocerans, water mites, turbellarians). A considerable number (27 taxa) belonged to the remaining faunal groups, considered as a whole. Lake Bracciano is characterized by the highest species richness found so far in lakes of Central Italy (Mastrantuono 1993) and the number of taxa was similar to that recorded in the nearby small Lake Martignano (119 taxa). The qualitative similarity between these two lakes was high (QS: 71.3\%) and also the qualitative composition and depth distribution of the submerged vegetation was nearly the same. As reported in a previous paper (Mastrantuono \& Mancinelli 2003) this high similarity could be partly a consequence of the artificial connection built between the lakes in historical times (1828) to increase water captation by the aqueduct. 
Tab. 3. List of identified taxa and respective percentages (annual means) in Lake Bracciano. $x=$ presence.

\begin{tabular}{|c|c|c|c|c|c|c|}
\hline Lake Bracciano - stations & 1 & 2 & 3 & 4 & 5 & Total \\
\hline PORIFERA & 0 & $\mathrm{x}$ & $\mathrm{x}$ & $\mathrm{x}$ & $\mathrm{x}$ & $\mathrm{x}$ \\
\hline \multicolumn{7}{|l|}{ HYDROIDA } \\
\hline Hydra sp. & 0.9 & 7.1 & 0.2 & 0.1 & 0.2 & 1.3 \\
\hline \multicolumn{7}{|l|}{ TURBELLARIA } \\
\hline Dugesia tigrina (Girard) & 0.07 & 0.4 & 0.5 & 0.1 & 0.06 & 0.2 \\
\hline Rhynchomesostoma rostratum (O.F.Müller) & 0.02 & 0 & 0 & 0.003 & 0.004 & 0.005 \\
\hline Gyratrix hermaphroditus Ehremberg & 0.07 & 0.01 & 0.05 & 0.005 & 0.01 & 0.02 \\
\hline Dendrocoelum lacteum (O.F.Müller) & 0 & 0 & 0.02 & 0.03 & 0.03 & 0.02 \\
\hline Opisthocystis sp. & 0.001 & 0 & 0 & 0.004 & 0 & 0.001 \\
\hline Macrostomum sp. & 0.8 & 0.4 & 0.5 & 0.2 & 0.3 & 0.4 \\
\hline Mesostoma sp. & 0.009 & 0.01 & 0 & 0 & 0.001 & 0.003 \\
\hline Dugesia sp. & 0 & 0 & 0.006 & 0 & 0 & 0.0008 \\
\hline Polycelis sp. & 0.001 & 0 & 0.01 & 0 & 0.02 & 0.008 \\
\hline Turbellaria not identified & 0.05 & 0.02 & 0.01 & 0.02 & 0.01 & 0.02 \\
\hline \multicolumn{7}{|l|}{ NEMATODA } \\
\hline Monhystera sp. & 0.1 & 0.08 & 0.1 & 0.4 & 0.05 & 0.2 \\
\hline Theristus setosus (Bütschli) & 0 & 0.01 & 0.02 & 0.02 & 0 & 0.01 \\
\hline Aphanolaimus aquaticus (Daday) & 0 & 0.004 & 0.02 & 0 & 0 & 0.003 \\
\hline Ethmolaimus pratensis De Man & 1.6 & 5.3 & 1.5 & 0.4 & 0.6 & 1.5 \\
\hline Chromadorita leuckarti (De Man) & 0 & 0.006 & 0.001 & 0 & 0 & 0.0009 \\
\hline Plectus sp. & 0.1 & 0.03 & 0.2 & 0.05 & 0.03 & 0.07 \\
\hline Tripyla glomerans (Bastian) & 0 & 0 & 0 & 0.001 & 0 & 0.0003 \\
\hline Tobrilus gracilis (Bastian) & 0.04 & 0.05 & 0.3 & 0.01 & 0.09 & 0.08 \\
\hline Tobrilus helveticus (Hofmänner) & 0.01 & 0.007 & 0 & 0 & 0 & 0.002 \\
\hline Tobrilus pellucidus (Bastian) & 0.004 & 0 & 0 & 0 & 0 & 0.0006 \\
\hline Tobrilus sp. & 0.07 & 0.07 & 0.2 & 0.05 & 0.03 & 0.07 \\
\hline Mononchus truncatus Bastian & 0 & 0 & 0.005 & 0 & 0 & 0.0006 \\
\hline Ironus tenuicaudatus De Man & 0.002 & 0.01 & 0.001 & 0 & 0.002 & 0.003 \\
\hline Dorylaimina & 3.7 & 1.2 & 5.4 & 0.8 & 1.5 & 2.1 \\
\hline TARDIGRADA & 0 & 0.002 & 0 & 0 & 0 & 0.0003 \\
\hline \multicolumn{7}{|l|}{ OLIGOCHAETA } \\
\hline Aeolosoma hemprichi (Ehrember) & 0.02 & 0.002 & 0 & 0 & 0.009 & 0.006 \\
\hline Chaetogaster diaphanus (Gruithuisen) & 0.05 & 0.007 & 0 & 0.003 & 0 & 0.009 \\
\hline Chaetogaster diastrophus (Gruithuisen) & 0.4 & 1.7 & 0.3 & 0.08 & 0.3 & 0.4 \\
\hline Pristina aequiseta Bourne & 0.004 & 0 & 0.4 & 0.1 & 0.002 & 0.08 \\
\hline Pristina foreli Piguet & 0.002 & 0.001 & 0.03 & 0.03 & 0 & 0.01 \\
\hline Stylaria lacustris (L.) & 0.2 & 0.03 & 0.01 & 0.4 & 0.03 & 0.2 \\
\hline Nais simplex Piguet & 0.08 & 0.03 & 0.002 & 0.1 & 0.01 & 0.06 \\
\hline Nais pardalis Piguet & 0.004 & 0 & 0 & 0 & 0 & 0.0006 \\
\hline Nais variabilis Piguet & 0.3 & 1.1 & 1.5 & 3.2 & 0.2 & 1.4 \\
\hline Nais communis Piguet & 0.3 & 0.04 & 0.006 & 0.005 & 0.002 & 0.06 \\
\hline Nais christinae Kasparzak & 0 & 0.01 & 0.01 & 0.05 & 0.002 & 0.02 \\
\hline Dero sp. & 0.6 & 0.07 & 0.6 & 3.1 & 0.05 & 1.1 \\
\hline Vejdovskyella intermedia (Bretscher) & 0 & 0.02 & 0.001 & 0 & 0.004 & 0.004 \\
\hline Aulodrilus pluriseta (Piguet) & 0 & 0.02 & 0 & 0 & 0.001 & 0.002 \\
\hline Potamothrix heuscheri (Bretscher) & 0.09 & 0.09 & 0.2 & 0.02 & 0.1 & 0.09 \\
\hline Limnodrilus hoffmeisteri Claparède & 0.008 & 0.01 & 0 & 0.003 & 0.004 & 0.005 \\
\hline Enchytraeidae & 0.002 & 0 & 0.002 & 0.001 & 0 & 0.0009 \\
\hline Lumbriculidae & 0 & 0 & 0 & 0 & 0.001 & 0.0003 \\
\hline HIRUDINEA & 0 & 0 & 0.001 & 0 & 0 & 0.0002 \\
\hline \multicolumn{7}{|l|}{ CLADOCERA } \\
\hline Bosmina longirostris (O.F. Müller) & 0.2 & 0.09 & 0.2 & 0.3 & 0.6 & 0.3 \\
\hline Eurycercus lamellatus (O.F. Müller) & 0.4 & 0.1 & 0.2 & 11.1 & 3.7 & 4.4 \\
\hline Ilyocryptus sordidus Lièvin & 0 & 0 & 0 & 0.001 & 0.1 & 0.04 \\
\hline Alonella excisa (Fischer) & 0.2 & 0.09 & 0.1 & 0.05 & 0.2 & 0.1 \\
\hline Alonella exigua (Lilljeborg) & 1.1 & 6.1 & 4.9 & 1.1 & 1.1 & 2.3 \\
\hline Chydorus sphaericus (O.F.Müller) & 9.5 & 0.7 & 6 & 5.2 & 1.2 & 4.2 \\
\hline Leydigia acanthocercoides (Fischer) & 0 & 0.05 & 1.1 & 0.01 & 0.001 & 0.1 \\
\hline Acroperus harpae (Baird) & 8.4 & 1.3 & 7 & 5.1 & 25.6 & 11.2 \\
\hline Alona quadrangularis (O.F. Müller) & 0.03 & 0.07 & 0.3 & 0.07 & 0.2 & 0.1 \\
\hline Alona rectangula Sars & 0.3 & 0.3 & 2.1 & 0.5 & 1 & 0.8 \\
\hline Alona guttata (Sars) & 0.1 & 0.04 & 0.09 & 0.1 & 0.3 & 0.1 \\
\hline Pleuroxus laevis Sars & 0.08 & 0.08 & 0.4 & 3 & 1.8 & 1.5 \\
\hline Camptocercus sp. & 0.2 & 0.07 & 0 & 0.1 & 0.04 & 0.08 \\
\hline
\end{tabular}


Tab. 3. Continuation.

\begin{tabular}{|c|c|c|c|c|c|c|}
\hline Lake Bracciano - stations & 1 & 2 & 3 & 4 & 5 & Total \\
\hline \multicolumn{7}{|l|}{ COPEPODA } \\
\hline Macrocyclops albidus (Jurine) & 11.3 & 7.8 & 11.2 & 12.5 & 20.3 & 13.7 \\
\hline Eucyclops serrulatus (Fischer) & 5 & 8.6 & 2.6 & 8.6 & 4.8 & 6.2 \\
\hline Eucyclops macruroides (Lilljeborg) & 11.9 & 13 & 14.8 & 8.5 & 8 & 10.3 \\
\hline Microcyclops varicans (Sars) & 1.2 & 1.5 & 6 & 0.2 & 1.2 & 1.6 \\
\hline Mesocyclops leuckarti (Claus) & 20.2 & 13 & 17.7 & 20.4 & 13.2 & 16.9 \\
\hline Harpacticoida & 0.8 & 0.2 & 0.2 & 0.1 & 0.1 & 0.2 \\
\hline \multicolumn{7}{|l|}{ OSTRACODA } \\
\hline Darwinula sp. & 0 & 0 & 0.001 & 0 & 0 & 0.0002 \\
\hline Limnocythere sp. & 0.02 & 0 & 0.001 & 0.006 & 0.07 & 0.03 \\
\hline Candona sp. & 0 & 0 & 0 & 0.005 & 0.0005 & 0.002 \\
\hline Strandesia sp. & 0.002 & 0.008 & 0 & 0.002 & 0.2 & 0.05 \\
\hline \multicolumn{7}{|l|}{ AMPHIPODÁ } \\
\hline Echinogammarus sp. & 0.06 & 0.3 & 0.1 & 0.08 & 0.008 & 0.08 \\
\hline \multicolumn{7}{|l|}{ DECAPODA } \\
\hline Palaemonetes antennarius (Milne Edwards) & 0.4 & 0.1 & 0.4 & 0.2 & 0.1 & 0.2 \\
\hline \multicolumn{7}{|l|}{ EPHEMEROPTERA } \\
\hline Cloeon gr. simile & 0.08 & 0.1 & 0.1 & 0.03 & 0.1 & 0.09 \\
\hline Caenis sp. & 0.005 & 0 & 0 & 0 & 0 & 0.0008 \\
\hline \multicolumn{7}{|l|}{ ODONATA } \\
\hline Cercion lindeni (Selys) & 0.006 & 0.02 & 0.005 & 0.003 & 0 & 0.005 \\
\hline Trithemis annulata (Palisot de Beauvais) & 0.001 & 0 & 0.001 & 0 & 0 & 0.0003 \\
\hline \multicolumn{7}{|l|}{ DIPTERA CHIRONOMIDAE } \\
\hline Orthocladiinae not iden. & 0.7 & 7.8 & 0.7 & 0.8 & 3.6 & 2.6 \\
\hline Pentaneurini & 0.1 & 0.05 & 0.3 & 0.05 & 0.2 & 0.1 \\
\hline Procladius & 0 & 0.004 & 0.001 & 0.002 & 0.002 & 0.002 \\
\hline Tanypodinae & 0 & 0 & 0 & 0.001 & 0.0005 & 0.0005 \\
\hline Tanytarsus & 0.04 & 0.2 & 0.3 & 0.03 & 0.02 & 0.09 \\
\hline Paratanytarsus & 1 & 5 & 1.4 & 0.3 & 0.6 & 1.3 \\
\hline Microtendipes & 0.04 & 0.05 & 0.2 & 0.003 & 0.002 & 0.04 \\
\hline Paratendipes & 0.01 & 0.04 & 0.5 & 0.001 & 0 & 0.07 \\
\hline Endochironomus & 0.03 & 0.006 & 0.04 & 0.03 & 0 & 0.02 \\
\hline Phaenopsectra & 0 & 0.2 & 0 & 0 & 0 & 0.02 \\
\hline Polypedilum nubeculosum gr. & 0.004 & 0.002 & 0.04 & 0.001 & 0 & 0.007 \\
\hline Polypedilum bicrenatum gr. & 0 & 0.01 & 0.2 & 0.001 & 0 & 0.03 \\
\hline Polypedilum laetum gr. & 0 & 0 & 0.002 & 0 & 0 & 0.0003 \\
\hline Polypedilum breviantennatum Chernovsky & 0.004 & 0.002 & 0.006 & 0 & 0 & 0.002 \\
\hline Polypedilum & 0 & 0.002 & 0.01 & 0.0005 & 0 & 0.002 \\
\hline Xenochironomus & 0 & 0.004 & 0.005 & 0.003 & 0 & 0.002 \\
\hline Dicrotendipes & 0.1 & 1.1 & 0.09 & 0.03 & 0.005 & 0.2 \\
\hline Glyptotendipes & 0.01 & 0.07 & 0.02 & 0.07 & 0.0005 & 0.04 \\
\hline Chironomus & 0.02 & 0.02 & 0.3 & 0.04 & 0.01 & 0.05 \\
\hline Cryptochironomus & 0 & 0.006 & 0 & 0.002 & 0 & 0.001 \\
\hline Parachironomus & 0.07 & 0.04 & 0.2 & 0.03 & 0.03 & 0.06 \\
\hline Cladopelma & 0 & 0.02 & 0.07 & 0 & 0 & 0.01 \\
\hline \multicolumn{7}{|l|}{ LEPIDOPTERA } \\
\hline Piralidae & 0 & 0.002 & 0.001 & 0.001 & 0 & 0.001 \\
\hline \multicolumn{7}{|l|}{ TRICHOPTERA } \\
\hline Orthotrichia costalis (Curtis) & 0.012 & 0.02 & 0.04 & 0.01 & 0.01 & 0.02 \\
\hline Hydroptila sp. & 0.006 & 0.009 & 0.006 & 0.0005 & 0.001 & 0.003 \\
\hline Ecnomus tenellus (Rambur) & 0.02 & 0.06 & 0.02 & 0.001 & 0.0005 & 0.02 \\
\hline Leptocerus sp. & 0.5 & 3.1 & 0.3 & 0.7 & 0.3 & 0.9 \\
\hline Trichoptera not identified & 0.02 & 0.04 & 0.09 & 0.03 & 0.009 & 0.03 \\
\hline \multicolumn{7}{|l|}{ ACARINA HYDRACARINA } \\
\hline Limnesia sp. & 0.9 & 1.3 & 0.3 & 0.7 & 0.8 & 0.8 \\
\hline Unionicola sp. & 0.9 & 0.9 & 0.7 & 1 & 0.2 & 0.7 \\
\hline Neumania sp. & 0.2 & 0.4 & 0.1 & 0.1 & 0.1 & 0.2 \\
\hline Hydrochoreutes sp. & 0.08 & 0.004 & 0.03 & 0.01 & 0.2 & 0.08 \\
\hline Lebertia sp. & 0.1 & 0.04 & 0.05 & 0.06 & 0.3 & 0.1 \\
\hline Oxus sp. & 0.009 & 0 & 0.005 & 0 & 0.003 & 0.003 \\
\hline Forelia sp. & 0.08 & 0.01 & 0.002 & 0.001 & 0 & 0.01 \\
\hline Acercus sp. & 1 & 0.3 & 0.2 & 1.5 & 0.7 & 0.9 \\
\hline Arrenurus sp. & 2.4 & 0.3 & 0.3 & 0.3 & 0.3 & 0.6 \\
\hline Hygrobates sp. & 0.1 & 0.001 & 0.01 & 0 & 0 & 0.02 \\
\hline Hydracarina not identified & 0.06 & 0.01 & 0.04 & 0.05 & 0.1 & 0.07 \\
\hline
\end{tabular}

(continued) 
Tab. 3. Continuation.

\begin{tabular}{lcccccc}
\hline Lake Bracciano - stations & 1 & 2 & 3 & 4 & 5 & Total \\
\hline ACARINA ORIBATEA & 0.03 & 0.004 & 0.02 & 0.003 & 0.007 & 0.01 \\
ACARINA HALACARIDAE & 3.6 & 1.9 & 0.7 & 2.1 & 0.8 \\
GASTROPODA & & & & 1.8 \\
Physa acuta (Draparnaud) & 0.003 & 0.03 & 0 & 0.008 & 0 & 0.008 \\
Lymnaea auricularia (L.) & 0.03 & 0.06 & 0.03 & 0.1 & 0.02 & 0.05 \\
Acroloxus lacustris (L.) & 0 & 0.01 & 0.002 & 0.02 & 0.007 & 0.01 \\
Theodoxus fluviatilis (L.) & 0.2 & 1.4 & 0.3 & 0.2 & 0.02 & 0.3 \\
Valvata piscinalis (Müller) & 0.08 & 0.004 & 0.007 & 0.04 & 0.1 & 0.06 \\
Bithynia tentaculata (L.) & 6.32 & 4 & 4.9 & 4.5 & 3.3 & 4.5 \\
Gyraulus crista (L.) & 0.006 & 0 & 0 & 0 & 0 \\
Planorbidae & 0 & 0 & 0.005 & 0.003 & 0.002 & 0.001 \\
Hydrobioidea & 0.1 & 0.05 & 0.01 & 0.2 & 0.2 \\
\hline
\end{tabular}

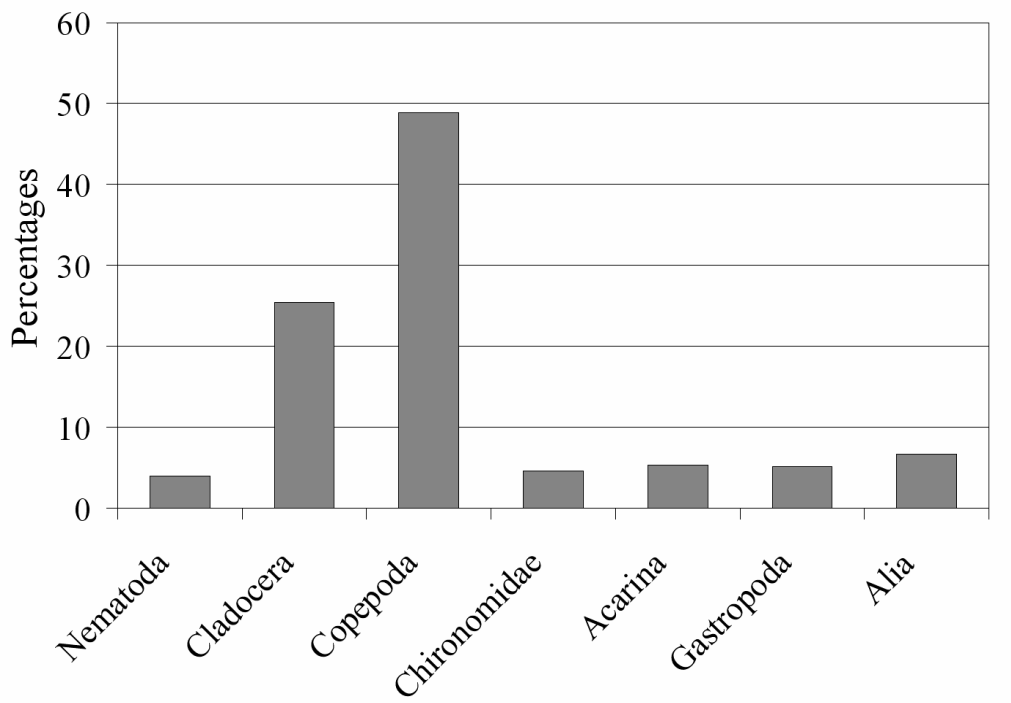

Fig. 3. Percentage composition (annual means) of faunal groups in Lake Bracciano.

In percentages the community was extensively characterized by microcrustaceans (copepods and cladocerans: 45.4 and $28.1 \%$ of the total fauna respectively, Fig. 3 ), followed by other groups (nematodes, oligochaetes, chironomids, water mites, gastropods), which displayed lower and comparable abundances and represented an important quantitative component. All the remaining invertebrates, considered altogheter (Alia in Fig. 3) constituted a secondary but significant percentage of the total fauna.

Frequencies of invertebrates revealed to be different with increasing depths (Fig. 4). The percentages of faunal groups showed a better distribution at greater depths $(8-15 \mathrm{~m})$, because microcrustaceans (copepods and cladocerans) reduced their numbers while oligochaetes, water mites and gastropods were more abundant. These latter groups are positively influenced by the stable presence of charales during the year, which ensure the survival and the numerical increase of invertebrates with typical benthic habits. Conversely the disappearance and/or seasonal decline of vegetation observed at shallower depth ranges $(0-4 \mathrm{~m}$ and 4-8 $\mathrm{m})$ was more favourable at microcrustaceans (Fig. 4), which have a more feeble association with plant substratum.

High qualitative similarity (QS values even higher than $80 \%$, Tab. 4) emphasized the very similar species composition of all sites of sampling. Conversely the relative abundances at the stations (Fig. 5), tested by PSc analysis, showed higher similarity among the sites 1-3-4 (values over 70\%), while site 2 and site 5 seemed less similar to the others (all PSc values are comprised between 53 and $63 \%$ ). The fauna structure in these stations displayed in fact significant differences because site 2 is characterized by the highest number of plant taxa (8), the better distribution of the frequencies among faunal groups (high percentages especially for chironomids and alia) and the highest diversity $(\mathrm{H}=$ 4.3). Site 5, which corresponds to the pipeline area, showed instead the lowest number of plant taxa, of species richness and diversity ( 2 plant taxa, 91 invertebrate taxa, $\mathrm{H}=3.7$ ) and the highest abundance of microcrustaceans, due the poor abundance of vegetation. 
- Nematoda Oligochaeta 目 Cladocera $\square$ Copepoda $\square$ Chironomidae

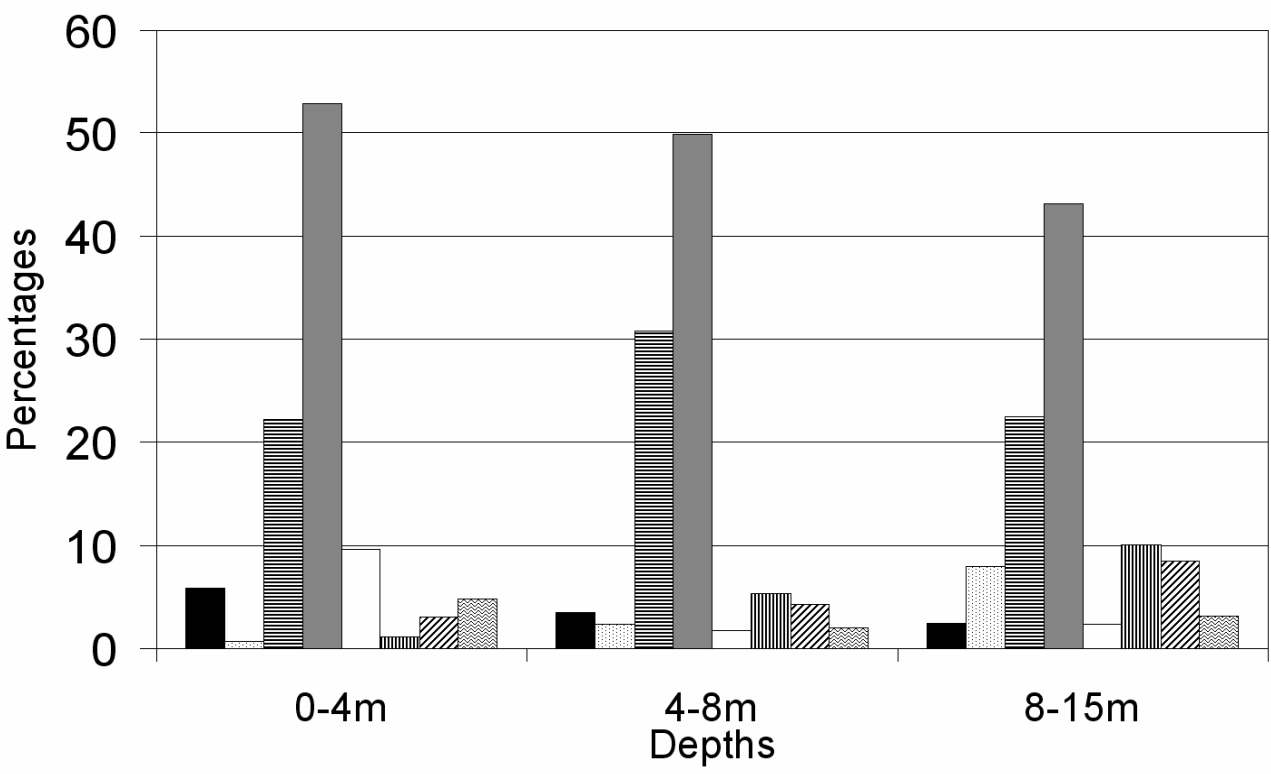

Fig. 4. Percentage composition (annual means) of the faunal groups at different depths in Lake Bracciano.

Tab. 4. Values of qualitative (QS) and quantitative (PSc) similarity of the community associated with plant substratum in the stations of Lake Bracciano.

\begin{tabular}{|c|c|c|c|c|c|c|c|c|c|c|c|}
\hline QS & 1 & 2 & 3 & 4 & 5 & PSc & 1 & 2 & 3 & 4 & 5 \\
\hline 1 & - & 85.3 & 82.2 & 84.5 & 83.9 & 1 & - & 59.9 & 78.0 & 73.5 & 63.3 \\
\hline 2 & - & - & 88.2 & 87.6 & 82.9 & 2 & - & - & 61.3 & 56.4 & 53.1 \\
\hline 3 & - & - & - & 86.6 & 81.9 & 3 & - & - & - & 66.8 & 59.0 \\
\hline 4 & - & - & - & - & 86.3 & 4 & - & - & - & - & 63.5 \\
\hline 5 & - & - & - & - & - & 5 & - & - & - & - & - \\
\hline
\end{tabular}

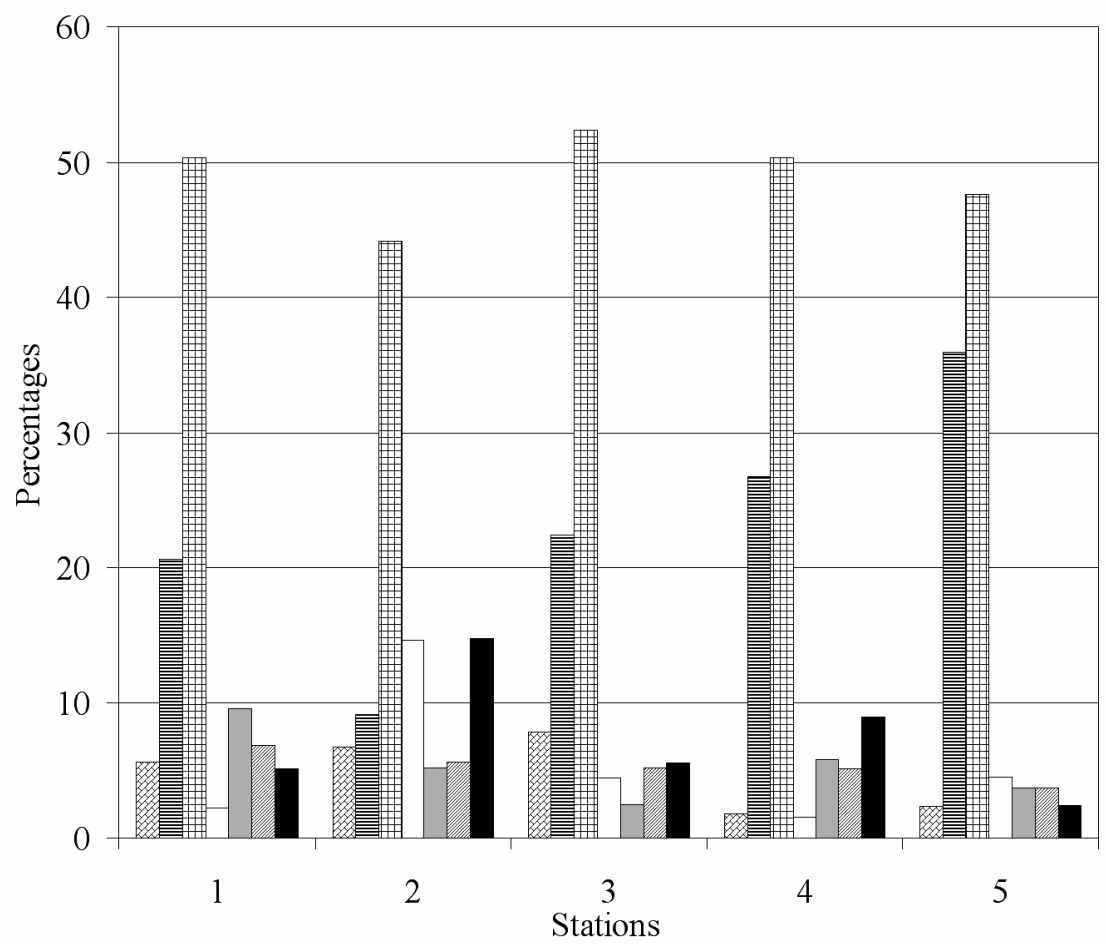

Fig. 5. Percentage composition (annual means) of the faunal groups at different stations in Lake Bracciano. 


\section{DISCUSSION AND CONCLUSIONS}

The intensification of the anthropogenic impact on freshwater ecosystems and the recent climatic changes occurred more rapidly and extensively over the last few decades, and this phenomenon required to change the object of the investigations on the lake littoral, which is an area strongly affected by impacts such as input of pollutants, shoreline alterations and water level reduction.

In this framework several recent studies, adressed mainly to shallow waters, have widely demonstrate that macrophyte-zoobenthos association represents one fundamental biological system for recycling organic material in the lake, and plays a relevant role in the maintenance of high environmental quality (Irvine et al. 1989; Van Donk et al. 1993; Schriver et al. 1995; Jeppesen et al. 1997; Søndergaard et al. 2000; Blindow et al. 2002). The great importance of the aquatic vegetation makes necessary at least a partial knowledge of its composition and abundance because it represents a key-element for obtaining a complete picture of the benthic community and an indication of quality deriving from several sources of biological data.

Depth range covered by vegetation, species richness, abundance of some bioindicator taxa have been considered as useful descriptors for a biomonitoring founded on aquatic plants. On this ground data collected in Lake Bracciano pointed on two contrasting results: the positive one is the extensive colonization with depth and the high abundance and distribution of charales, macroalgae associated with low trophic levels (PereyraRamos 1981; Blindow 1992; Melzer 1992). Charales are also a very important biological component because their biomass uptakes a considerable quantity of phosphorus during all seasons, and it contributes at the reduction of the nutrient load in the lake. Moreover, dense carpets of charales increases transparency in littoral waters preventing the sediment resuspension from sublittoral bottoms (Kufel \& Ozimek 1994; Van den Berg et al. 1999; Blindow et al. 2002). The negative result is the low number of plant taxa found in the collected samples (9 taxa), which depends mainly on the unusually poor composition observed at low depth range $(0-4 \mathrm{~m})$. Moreover in two of the five stations (3 and 5) the species richness was very low (Tab. 2). This poor species richness may be partly a consequence of a negative and considerable disappearance of the common reed bed, due the intense shore management. This reduction increases the instability of more littoral bottoms and the washing away of organic material in more profundal bottoms and this phoenomenon can influence macrophytes both in number and abundance just in the shallower depth range $(0-4 \mathrm{~m})$, which is the most favourable area for vegetation blooming.

As observed for plant substrate, also the biomonitoring based on invertebrate fauna requires necessarily a set of parameters (both bioindices and bioindicators) to obtain a diagnosis of environmental quality. This necessity is directly related with the complexity of the quali-quantitative composition of this community and with its high homeostatic capability against environmental modifications. Surely the wide range of possible adjustments of the fauna structure in space and time constitutes one of the most important difficulty to consider single parameters as exhaustive for a reliable biomonitoring (Mastrantuono 1993). So, previous studies were aimed to select the more useful elements of evaluation, which are recognized as percentage community composition, species richness and diversity, numbers of individuals, number and/or percentages of some bioindicator species or higher taxa.

The meio-macroinvertebrate fauna in Lake Bracciano was characterized by high species richness (125 taxa), which is, as above recorded, the highest found so far in lakes of Central Italy and it is the first positive result. Moreover taxa were well distributed among different invertebrate groups, each characterized by high number of species (Tab. 3). As widely verified in previous investigations (Mastrantuono 1993) also in Lake Bracciano the fauna was quantitatively dominated by microcrustaceans (Fig. 5), but the very important characteristic for an evaluation of positive ecological status is the quantity reached by other invertebrates in comparison to microcrustaceans. On this matter two positive elements have been obseved: the first one is the notable percentage of several benthic groups (nematodes, chironomids, water mites and gastropods, each one found with values comprised between 4 and $5.3 \%$ of the total fauna, Fig. 5). The second positive element is the high percentage of all the remaining groups, summarized together as Alia (Fig. 5, range: 2.4$14.7 \%$ of the total fauna). Species richness and abundances well distributed among several invertebrate groups showed to be a very important and positive characteristic of the faunal structure because a higher presence of organisms having different feeding habits involves a more efficient nutrient recycling. For this reason, when any water quality deterioration modifies food chain, the most sensitive invertebrates are first of all influenced and in a short time decrease in abundance or disappear completely, as verified in other studied lakes (Mastrantuono 1993). Measures of the Shannon index have clearly evidenced the good distribution of the abundances among all the identified taxa (Tab. 3). Table 5 shows that diversity was very high at different sites (always higher than 4.0, excluding st. 5), at different depth ranges and also in different seasons: the highest value occurred in winter (4.7, December 1998), and the lowest in summer (3.4). Therefore diversities are always greater than 3.0 and it can be considered a synthetic indication of good ecological status.

Faunal density (semiquantitative data, expressed as annual means of counted organisms per meter in depth of bottom colonized by aquatic plants, table 6) showed 
Tab. 5. Shannon diversity $(\mathrm{H})$ of the community associated with submerged macrophytes in Lake Bracciano at different stations, dates and depths.

\begin{tabular}{cccccc}
\hline Stations & 1 & 2 & 3 & 4 & 5 \\
\hline $\mathrm{H}$ & 4.1 & 4.3 & 4.2 & 4.0 & 3.7 \\
\hline Dates & $\mathrm{V} / 1998$ & $\mathrm{VII} / 1998$ & $\mathrm{X} / 1998$ & $\mathrm{XII} / 1998$ & $\mathrm{II} / 1999$ \\
\hline $\mathrm{H}$ & 3.9 & 3.4 & 3.7 & 4.7 & 3.9 \\
\hline Depths & $0-4 \mathrm{~m}$ & $4-8 \mathrm{~m}$ & $8-15 \mathrm{~m}$ & & \\
\hline $\mathrm{H}$ & 4.0 & 4.3 & 4.3 & & \\
\hline
\end{tabular}

Tab. 6. Bioindices and bioindicators of the community associated with submerged vegetation used for a quality evaluation in Lake Bracciano. Total fauna is the total numbers of organisms (semiquantitative data, expressed as annual means per meter in depth of bottom colonized by aquatic plants).

\begin{tabular}{lcccccc}
\hline Stations & 1 & 2 & 3 & 4 & 5 & Total \\
\hline Plant colonization (m) & $0-15$ & $0-15$ & $0-15$ & $0-15$ & $0-15$ & $0-15$ \\
Total fauna & 1356 & 1193 & 1083 & 2475 & 2444 & 1710 \\
Number of taxa & 95 & 102 & 102 & 99 & 91 & 125 \\
Diversity (H) & 4.1 & 4.3 & 4.2 & 4.0 & 3.7 & 4.1 \\
Nr. of cladoceran species & 11 & 12 & 11 & 13 & 13 & 13 \\
Chydorus sphaericus (\%) & 9.5 & 0.7 & 6.0 & 5.2 & 1.2 & 4.2 \\
Nr. of gastropod taxa & 7 & 7 & 7 & 8 & 8 & 9 \\
Hydrobioidea (\%) & 0.1 & 0.05 & 0.01 & 0.2 & 0.2 & 0.1 \\
Decapoda (\%) & 0.4 & 0.1 & 0.4 & 0.2 & 0.1 & 0.2 \\
Porifera (presence) & - & $*$ & $*$ & $*$ & $*$ & $*$ \\
\hline
\end{tabular}

to be very low, also in this case the lowest values so far measured in lakes of Central Italy (Mastrantuono \& Mancinelli 2002), and this can represent an indication of low trophic degree in the water.

An evaluation of low trophy emerged also by results on presence/abundance of the main bioindicators which are: number of cladoceran species, percentage of the microfilterer cladoceran Chydorus sphaericus and number of gastropod taxa. These taxa were selected as the most appropriate indicators on a comparative analysis of the considerable body of data previously collected in other lakes studied (Mastrantuono 1986, 1987, 1990, 1991, 1993; Mastrantuono \& Mancinelli 1999; Mastrantuono et al. 2000) and on several international studies regarding these invertebrates (Mouthon 1981; Kořínek et al. 1985; Berzinš \& Bertilsson 1989; Costil \& Clement 1996; Mouthon \& Charvet 1999). Cladocerans and gastropods are known traditionally to play a significant role in the trophic evaluation of freshwaters because they filter phytoplankton or graze actively on periphyton. For this reason a high number of species belonging to these invertebrates is a positive situation because their feeding habits involve an efficient removal of algal populations and improve water clarity. (Brönmark 1989; Costil \& Clement 1996; Pinowska 2002). On this point of view the number of cladoceran species in the lake was high both as total number (13) and as presence at the stations (everywhere higher than 10 species, Tab. 6). Moreover, Chydorus sphaericus, considered in high abundances an indicator of meso-eutrophy (Berzinš \& Bertilsson 1989; de Eyto 2001), reached low or moderate percentages (annual mean range at the stations: $0.7-9.5 \%$ ). In a similar way, gastropods comprised a relatively high number of taxa (9) well distributed at all sites, including a significant finding of Hydrobioidea, described as bioindicators of good environmental conditions (Mouthon \& Charvet 1999). The positive evaluation of water quality was furtherly supported by findings of sensitive organisms such as sponges and decapodes (range of this latter crustaceans: $0.1-0.4 \%$ ).

In synthesis, all descriptors examined in the present investigation converge to a diagnosis of good ecological status, close to oligotrophy. The extensive colonization of Charales, similar to that observed in the past (Barbanti et al. 1971), identifies Bracciano as a Charalake and all parameters characterizing invertebrate community represent significant evidences of low trophy. High transparency values (range: 8-14 m, mean: $11.8 \mathrm{~m}$ ) and low nutrient contents in the water (Tab. 1) complete this diagnosis.

Despite any direct comparison can be made between present and past fauna composition (Nocentini 1973; Bazzanti 1981), because these studies regarded different substrates and only some of the invertebrates considered in the present investigation, a remarkable observation is that the positive environmental status suggested in previous studies appeared to be maintained. But, 
although a positive picture emerged from this analysis, it must be evidenced an increasing influence of the urbanization and of the recreational use of the lakeshore on littoral communities. These processes carried to a progressive disappearance of the reed thicket, which negatively influenced the colonization of more littoral depth range $(0-4 \mathrm{~m})$ both by submerged plants and invertebrates. The negative effect of a poor submerged vegetation was evident especially at site 5, which showed the lowest number of plant taxa (2), and the lower species richness (91 taxa) and diversity $(\mathrm{H}=3.7)$. Moreover, higher abundance of microcrustaceans and reduced percentages of several invertebrates associated with plant substrate clearly charactererized this site (Tab. 6), located in the area of the pipeline.

It may be possible a future negative impact of the progressive reduction of plant colonization on more profundal littoral bottoms and, in a cascade effect, on sublittoral bottoms. The increase of water captation and the consequent water level reduction will cause a further serious damage at the littoral zone and thus at the food chain in the lake. With this perspective a deterioration in the recreational and aesthetic value of the lakeshore may likewise happen. So the present investigation provides the most complete picture available so far on littoral fauna associated with plant substrate which can be used in the future bioassessment of the lake ecosystem.

\section{REFERENCES}

Barbanti, L., G. Bonomi, A. Carollo, G. Chiaudani, I. Ferrari, M. Gerletti, A.M. Nocentini, D. Ruggiu \& L.Tonolli. 1971. Limnologia ed ecologia dei laghi di Bolsena, Bracciano, Trasimeno e Vico: situazione attuale e prevedibili conseguenze derivanti da una loro utilizzazione multipla. Ist. ital. Idrobiol., Verbania Pallanza: $263 \mathrm{pp}$

Bazzanti, M. 1981. Survey of the macrobenthic community in an area of Lake Bracciano (Central Italy). Boll. Zool., 48: 295-303.

Bazzanti M. \& M. Seminara. 2003. Sublittoral and profundal benthic communities as indicators of environmental stress in the Central Italian volcanic lakes: a proposal for monitoring. Proc. Int. Conf. "Residence Time in Lakes: Science, Management, Education". Bolsena (VT), 29 settembre-3 ottobre 2002.

Berzinš, B. \& J. Bertilsson. 1989. On limnic microcrustaceans and trophic degree. Hydrobiologia, 185: 95-100.

Blindow, I. 1992. Decline of charophytes during eutrophication: comparison with angiosperm. Freshwat. Biol., 28: 9-14.

Blindow, I., A. Hargeby, B.M.A.Wagner \& G. Andersson. 2000. How important is the crustacean plankton for the maintenance of water clarity in shallow lakes with abundant submerged vegetation? Freshwat. Biol., 44: 185197.

Blindow, I., A. Hargeby \& G. Andersson. 2002. Seasonal changes of mechanisms maintaining clear water in a shallow lake with abundant Chara vegetation. Aquat. Bot., 72: 315-334.

Brönmark, C. 1989. Interactions between epiphytes, macrophytes and freshwater snails: a review. J. Moll. Stud., 55: 299-311.
Bruno, G. 1985. Bracciano sewerage system amd sewage treatment plant automatic control. Proc. Int.Congress "Lakes pollution and recovery". (ANDIS), Roma: 194-198.

CEC. 2000. Council of European Communities. Directive 2000/60 EC of 23 October 2000 establishing a framework for community action in the water policy. Official Journal of the European Communities, L327/1.

Costil, K. \& B. Clement. 1996. Relationship between freshwater gastropods and plant communities reflecting various trophic levels. Hydrobiologia, 321: 7-16.

De Eyto, E. 2001. Chydorus sphaericus as a biological indicator of water quality in lakes. Verh. int. Ver. Limnol., 27: 3358-3362.

Dieter, C.D. 1990. The importance of emergent vegetation in reducing sediment resuspension in wetlands. J. Freshwat. Ecol., 5: 467-473.

Ferrara, O. 1984. Struttura e dinamica della comunità zooplanctonica in un'area del Lago di Bracciano (Lazio). Riv. Idrobiol., 23: 145-158.

Ferrara, O., D. Vagaggini \& F.G. Margaritora. 2002. Zooplankton abundance and diversity in Lake Bracciano, Latium, Italy. J. Limnol., 6: 169-175.

Ferrari, I. 1972. Structure and dynamics of pelagic zooplankton in Lakes Bolsena, Bracciano, and Vico (Central Italy). Mem. Ist. ital. Idrobiol., 29: 209-227.

Gaggino, G.F., R. Marchetti, E. Cappelletti \& T. Calcagnini. 1985. La qualità delle acque dei laghi italiani negli anni '80. Atti Congr. Int. EWPCA. Andis Ed.: 5-44.

Horppila, J. \& L. Nurminen. 2001. The effect of an emergent macrophyte (Tipha augustifolia) on sediment resuspension in a shallow north temperate lake. Freshwat. Biol., 46: 1447-1455.

Irvine, K., B. Moss \& H. Balls. 1989. The loss of submerged plants with eutrophication II. Relationships between fish and zooplankton in a set of experimental ponds, and conclusions. Freshwat. Biol., 22: 89-107.

James, M.R., I. Hawes \& M. Weatherhead. 2000. Removal of settled sediments and periphyton from macrophytes by grazing invertebrates in the littoral zone of a large oligotrophic lake. Freshwat. Biol., 44: 311-326.

James, W.F. \& J.W. Barko. 1990. Macrophyte infuences on the zonation of sediment accretion and composition in a north-temperate lake. Arch. Hydrobiol., 20: 129-142.

Jeppesen, E., J.P. Jensen, M. Søndergaard \& T. Lauridsen. 1997. Top-down control in freshwater lakes: the role of nutrient state, submerged macrophytes and water depth. Hydrobiologia, 342/343: 151-164.

Kořínek, V., Křepelová-Macháčková, B. \& J. Macháček. 1985. Filtering structures of Cladocera and their ecological significance. II. Relation between the concentration of the seston and the size of filtering combs in some species of the genera Daphnia and Ceriodaphnia. Věst. čs. Společc. Zool., 50: 244-258.

Kufel, L. \& T. Ozimek. 1994. Can Chara control phosphorous cycling in Lake Luknajno (Poland)? Hydrobiologia, 275/276: 277-283.

Lodge, D.M. 1986. Selective grazing on periphyton: a determinant of freshwater gastropod microdistribution. Freshwat. Biol., 16: 831-841.

Losito, C. 1904. Entomostraci pelagici del Lago di Bracciano. Tipografia Nazionale di G. Bertero e C., Roma.

Margalef, R. 1957. La teoria de la information en ecologia. Mem. Real Acad. ciencias y artes de Barcelona, 32: 373449.

Martini, P. 1985. The project CO.B.I.S. plants. Proc. Int. Congress "Lakes pollution and recovery". ANDIS, Roma: 194-198.

Mastrantuono, L. 1986. Community structure of the zoobenthos associated with submerged macrophytes in the eutrophic Lake Nemi (Central Italy). Boll. Zool., 53: 41-47. 
Mastrantuono, L. 1987. Invertebrate community in the littoral regulated area of a hydroelectric lake-reservoir (Lake Campotosto, Central Italy). Riv. Idrobiol., 26: 17-32.

Mastrantuono, L. 1990. Composition and distribution of the zoobenthos associated with submerged macrophytes in Lake Albano (Italy) and environmental quality in the littoral. Riv. Idrobiol., 29: 709-727.

Mastrantuono, L. 1991. The zoobenthos associated with submerged macrophytes in littoral areas of Lake Vico (Italy): some relations between fauna structure and water quality. Limnetica, 7: 153-162.

Mastrantuono, L. 1993. Zoobenthos associated with submerged macrophytes and evaluation of trophic status in lakes. Verh. int. Ver. Limnol., 25: 780-783.

Mastrantuono, L. 1995. Composition and structure of the invertebrate fauna in littoral sandy shores of Lake Bracciano (Central Italy) and water quality monitoring. Limnetica, 11: 17-27.

Mastrantuono, L. \& T. Mancinelli. 1999. Long-term changes of zoobenthic fauna and submerged vegetation in the shallow Lake Monterosi (Italy). Limnologica, 29: 160-167.

Mastrantuono, L. \& T. Mancinelli. 2002. Twenty years study of the zoobenthos associated with aquatic vegetation in the volcanic lakes of Central Italy: species composition, biodiversity and water quality assessment. Int. Conf. "Residence times in lakes: Science, Management, Education". Bolsena (Italy): 210-214.

Mastrantuono, L. \& T. Mancinelli. 2003. Meio-macrobenthic invertebrates associated with submerged vegetation in a Chara-Lake (Lake Martignano, Italy). Atti Ass. Ital. Oceanol. Limnol., 16: 187-201.

Melzer, A. 1992. Submerged macrophytes. Arch. Hydrobiol., 38: 223-227.

Mouthon, J. 1981. Les mollusques et la pollution des eaux douces: ébauche d'une gamme de polluosensibilité des espéces. Bij. Dierkd., 51: 250-258.

Mouthon, J. \& S. Charvet. 1999. Compared sensitivity of species, genera and families of Molluscs to biodegradable pollution. Annls. Limnol., 35: 31-39.

Nocentini, A.M. 1973. La fauna macrobentonica litorale e sublitorale dei laghi di Bolsena, Bracciano e Vico (Italia Centrale, Lazio). Mem. Ist. ital. Idrobiol., 30: 97-148.

Received: December 2004

Accepted: February 2005
Pereyra-Ramos, E. 1981. The ecological role of Characeae in the lake littoral. Ekol. Pol., 29: 167-209.

Pinowska, A. 2002. Effects of snail grazing and nutrient release on growth of the macrophytes Ceratophyllum demersum and Elodea canadensis and the filamentous green alga Cladophora sp. Hydrobiologia, 479: 83-94.

Renkonen, O. 1938. Statistisch-ökologische Untersuchungen über die terrestrische Kaferwelt der finnischen Bruchmoore. Ann. Zool. Soc. Zool. Bot. Fenn. Vanamo, 6: $1-231$.

Schriver, P., J. Bøgestrand, E. Jeppesen \& M. Søndergaard. 1995. Impact of submerged macrophytes on fishzooplankton-phytoplankton interactions: large-scale enclosure experiments in a shallow eutrophic lake. Freshwat. Biol., 33: 255-270.

Sommani, E. 1961. Osservazioni sulle variazioni quantitative di Entomostraci planctonici nel lago di Bracciano. Boll. Pesca Piscic. Idrobiol., 16: 87-94.

Søndergaard, M., E. Jeppesen, J.P. Jensen \& T. Lauridsen. 2000. Lake restoration in Denmark. Lakes \& Reservoirs. Research and Management, 5: 151-159.

Sørensen, T. 1948. A method of stabilizing groups of equivalent amplitude in plant sociology based on the similarity of species content and its application to analysis of the vegetation on Danish commons. Biol. Skr., 5: 1-34.

Timms, R.M. \& B. Moss 1984. Prevention of growth of potentially dense phytoplankton populations by zooplankton grazing in the presence of zooplanktivorous fish in a shallow wetland ecosystem. Limnol. Oceanogr., 29: 472-486.

Van Den Berg, M.S., H. Coops, R. Noordhuis, J. Van Schie \& J. Simons. 1997. Macroinvertebrate communities in relation to submerged vegetation in two Chara-dominated lakes. Hydrobiologia, 342/343: 143-150.

Van Donk, E., R.D. Gulati, A. Iedema \& J.T. Meulemans. 1993. Macrophyte-related shifts in the nitrogen and phosphorous contents of the different trophic levels in a biomanipulated shallow lake. Hydrobiologia, 251: 19-26.

White, J \& K. Irvine. 2003. The use of littoral mesohabitats and their macroinvertebrate assemblages in the ecological assessment of lakes. Aquatic Conserv. Mar. Freshw. Ecosyst., 13: 331-351. 